\title{
Two decades of post-socialism in Serbia: Lessons learned and emerging issues in human resource management ${ }^{*}$
}

\author{
Biljana Bogićević Milikić, Nebojša Janićijević, Božidar Cerović***
}

The success and speed of transition processes in post-socialist countries produced quite different results regarding theirs institutional and economic systems. As far as Human Resources Management (HRM) practices are concerned, the main challenge for managers in these countries seem to be how to efficiently replicate HRM practices from the Western capitalistic countries, taking into account the fact that there are considerable differences in institutional, cultural and economic contexts. A few available empirical studies from Serbia revealed mixed findings suggesting that there are evident signs of both forces - the convergence and the divergence of HRM practices in Serbia compared to the Western ones. The aim of this paper, therefore, is to investigate HRM practices in Serbia, in order to shed light on some emerging issues in HRM, which may be of significance regards further studies.

Der Erfolg und die Geschwindigkeit von Übergangsprozessen in ehemals sozialistischen Ländern produzieren relativ unterschiedliche Ergebnisse im Hinblick auf ihr institutionelles und wirtschaftliches System. Bezüglich der HRMPraktiken scheint die größte Herausforderung für Manager in diesen Ländern zu sein, wie man effizient HRM-Praktiken aus westlichen Ländern, unter Berücksichtigung der unterschiedlichen institutionellen, wirtschaftlichen und kulturellen Kontexte, anwenden kann. Einige verfügbare Studien aus Serbien ergaben unterschiedliche Ergebnisse im Bezug auf die Existenz von beiden Kräften - Konvergenz und Divergenz - der HRM-Praktiken in Serbien im Vergleich zu westlichen Ländern. Das Ziel dieses Artikels ist, HRM-Praktiken in Serbien zu untersuchen, um einige weitere Fragen der HRM zu beleuchten, die möglicherweise von großer Bedeutung für weitere Studien sein könnten.

Keywords: transition, human resource management practices, crossvergence, transvergence

\footnotetext{
Manuscript received: 16.11.2011. accepted: 19.05.2012. (1 revision)

** Biljana Bogićević Milikić, Faculty of Economics, University of Belgrade; Main research areas: Human resource management, Comparative HRM, Organisational design, Organisational behaviour. Corresponding address: bbiljana@eunet.rs

Nebojša Janićijević; Faculty of Economics, University of Belgrade; Main research areas: Organisational change, Organisational design, Organisational behaviour, Performance management.

Božidar Cerović; Faculty of Economics, University of Belgrade; Main research areas: Transition economies, Comparative economics.
} 


\section{Introduction}

Transition towards a free-market economy and the entry of foreign companies on the Eastern European markets have encouraged companies in these countries to commence management technologies and to apply tools universally recognized and established in developed market economies. Within relevant literature there is a lack of comprehensive studies relating to HRM practices in the Central and Eastern European transition economies (Zupan/Kaše 2005: 883). This shortage of applicable empirical studies makes the challenge of introducing HRM systems and practices for the managers in these countries even greater having in mind that there are many critical differences between developed countries' and Eastern European transition economies' institutional contexts which may inhibit convergence (Sparrow/Hiltrop 1994; Holden 2001). Nonetheless, as suggested in the literature, the scope and speed of the transition process appear to be the key for changing the institutional or the "external HR context" (Zupan/Kaše 2005). However, success and speed of transition processes in different post-socialist countries, measured by the speed and the nature of privatization and corporate restructuring, the scope and extent of liberalization and degree of macroeconomic stabilization, produced rather diverse results regarding their institutional and economic systems. As the transition process is moving ahead, the institutional context will radically change towards Western developed market economies and will become an inevitable drive towards homogenization (DiMaggio/Powell 1983), so it may be expected that the organizations will change the dominant traditional personnel management concept towards comprehensive application of the HRM concept applied in industrialized Western capitalistic countries.

In this paper we attempt to investigate HRM practices in Serbia, after two decades of post-socialism, in order to shed light on lessons learned and open issues in HRM. Firstly, we investigate whether some changes occur in the area of HRM as related to the post-socialist period. Second, we analyze the character of changes that occur in the area of HRM with regard to the convergencedivergence debate. Third, we identify factors that influence both the evident changes of HRM practices in Serbia, as well as the forces promoting the status $q u o$ in this area.

The paper consists of three parts. Firstly, we present an overview of plausible trends in HRM as the consequence of post-socialist period offered by the relevant literature. Then we present HRM practices in Serbia, starting with traditional mode and analyzing the changes which have occurred during the post-socialist period. Finally, we draw lessons learned and identify some open issues in HRM, which may be of interest for future research, especially with the relevance for transition countries. 


\section{Plausible outcomes of the post-socialist period: convergence vs. divergence vs. crossvergence vs. transvergence of HRM practices}

For the transition countries focused on application of Western management technologies and systems one important issue is certainly related to the convergence-divergence debate, which may help to understand why a variety of different HRM practices have occurred during post-socialism in Eastern Europe and whether there is some distinctive HRM model present only in post-socialist countries .

The convergence perspective is related to the early research of technology impact on organizational systems, and suggests that the use of similar technologies produces similar organizational systems (Kerr et al. 1960) and creates a managerial homogeneity (Celestino 1999). With regards to the developing and transition countries, the convergence perspective would mean that they are expected to learn ideologically motivated values widespread in industrialized, capitalistic Western countries (Yip 1992; Kordonsky 1992). Regarding the question how does the convergence of HRM practices in transition economies actually occur, the institutional theory offers an explanation. The main idea is that organizations sharing the same environment are characterized by shared systems of meanings and tend to become 'isomorphic' with each other (Bjorkman 2006: 464), through the following mechanisms: (1) coercive isomorphism to gain legitimacy, where a powerful constituency imposes certain patterns on the organization; (2) mimetic isomorphism to avoid uncertainty, where organizations in uncertain situations adopt the pattern exhibited by successful organizations in their environment; (3) normative isomorphism, which derives from professionals who act as disseminators of suitable organizational archetypes which are then implemented by organizations under the influence of professional organizations such as universities, consultancy firms etc. (DiMaggio/Powell 1983). Thus, practices are adopted not because of 'effectiveness', but because of three specific social forces (McKinley et al. 1995): (1) 'constraining' forces, (2) 'cloning' forces, and (3) 'learning' forces.

The convergence perspective may be of interest for better understanding of HRM development in Serbia, since the transition process and the entrance of foreign companies into the Serbian market brought a broad awareness of the HRM approach among Serbian organisations regardless of their size, maturity, industrial sector or ownership, so becoming an institutionally accepted pattern of behaviour. Furthermore, the Serbian state administration introduced the HR departments in all government organizations as mandatory, as advised by Law. These developments are in particular unexpected taking into account the fact that not so long ago HRM practices in Serbia were rather weak and fixed upon mainly administrative issues and the traditional approach to HRM, as it was the case in some other ex-socialist countries such as Bulgaria, Czech Republic 
(Koubek/Vatchkova 2004) and Slovenia (Zupan/Kaše 2005). When introducing the HRM systems and policies many Serbian organisations looked at the "North American HRM model" (Brewster et al. 2004), in spite of more than a few critical differences between the North American and the Serbian institutional contexts, including economic environment, institutional environment, and cultural and social norms and tradition, which may prevent convergence (Holden 2001).

In this context, from the institutional perspective, it would be challenging to investigate whether HRM, widely accepted as a product of the North American setting (Gooderham et al. 2004), is easily transferable to the Serbian context, especially in sight of the characteristics of the Serbian political and economic system and national culture, which are quite different from the North American setting, and may effectively postpone full convergence.

In contrast, the divergence perspective points out the importance of focusing on national differences and attempts to explain continuing HRM diversity between (and even within) countries, even those grouped together as 'regions'. There are two types of explanatory factors which may prevent transition countries to fully implement Western management systems and technologies: cultural and institutional (Holden 2001; Sorge 2004). According to cultural approach, cultural differences further cause differences in organizational behaviours including work motivation, communications, conflicts, work-orientation, definition of goals, performance appraisal and rewarding, decision making and management style (Hofstede 1980; Laurent 1986; Schneider 1992; Schwartz 1994; Schneider/Barsoux 1997; Schuler/Rogovsky 1998; Li/Karakowsky 2001; Rollinson/Broadfield 2002; Trompenaars/Hampden-Turner 2004; Aycan 2005; Tayeb 2005; Stone/Stone-Romero 2008). The cultural values do have a prevailing influence on daily working behaviours of employees and managers (Schuler et al. 2001), so the national culture, not economic ideology, drives values of managers and employees. As a consequence, individuals, organizations and nations will retain their diverse, culturally determined values regardless of economic ideology (Evans 1970, according to Ralston et al. 1997; Cole 1973). Consequently, Serbia, with a history of socialism and cultural values such as high collectivism, high power distance, high uncertainty avoidance and femininity (Hofstede 1980; 2001a; 2001b), would not shift its work values toward those held in Western capitalistic countries, regardless of how industrialization occurs (Shaw et al. 1991; Ralston et al. 1997). Additional factors causing the potential distinctiveness of HRM practices in Serbia may be several institutional factors such as tradition, political system, historical path of industrialization, features of capital and labour markets, type of corporate governance system, legal and education systems (Holden 2001), and the degree of competence of HR professionals (Sparrow/Hiltrop 1994; 1997). Yet, the divergence perspective takes no account of change over time (Brewster 2006). 
By going beyond the two extremes, a more recent perspective, crossvergence, has argued that neither of these views is adequate to explain the dynamic interaction of economic ideology and national culture, and the integration of cultural and ideological influences would result in a distinctive value system that draws on both national culture and economic ideology (Ralston et al. 1993). (Ralston et al. 1997) argue that crossvergence is "something different", rather than something 'in between', since "crossvergence occurs when an individual incorporates both national culture influences and economic ideology influences synergistically to form a unique value system that is different from the value set supported by either national culture or economic ideology (p. 183)." In the case of HRM in Serbia, the crossvergence perspective may potentially be valid in explaining the changes that occurred in the last two decades. In terms of the dynamics of interaction between the economic ideology and the national culture, it can be assumed that the HRM system and practices in Serbia will change in some aspects and in some areas because of a strong need to adjust to the modern HRM present in developed economies and world-wide known companies. On the other hand, in some areas and in some aspects, HRM systems and practices in Serbia will remain the same because of the pressure of existing values and assumptions coming from a national culture. So, from the crossvergence perspective it may be interesting to see in which areas can modern HRM concepts and practices be implemented regardless of the incompatibility of the national culture's values, and in which areas modern HRM models and practices should be modified and adjusted to the local context, both in cultural terms and in terms of the availability of human skills (Tayeb 1995: 602).

On the basis of the crossvergence view, Gupta and Wang (2003) proposed additional perspective - transvergence in the context of studying emerging markets. According to them, although crossvergence aims to integrate the twin forces of technological capability (associated with convergence) and cultural embeddedness (associated with divergence), there is an additional alternative approach in situations when managers must integrate global models with their national and organizational culture. They define transvergence as "a formative change in the strategic modalities of an organization's business through a creative reinterpretation and reapplication of indigenous culture and emergent market and technological opportunities. (p. 69)" They argue that the presence as well as absence of cultural embeddedness and technological capability has an important influence on the strategic business model of the emerging markets under globalization (see Table 1). 
Table 1: Gupta \& Wang's framework for the influence of globalization on the strategic business model of the emerging markets

\begin{tabular}{|c|c|c|c|}
\hline & \multicolumn{2}{|c|}{ Cultural embeddedness ${ }^{1}$} \\
\hline & & $\begin{array}{l}\text { Low } \\
\text { (the acceptance of } \\
\text { foreign practices tends } \\
\text { to be higher) }\end{array}$ & $\begin{array}{c}\text { High } \\
\text { (the acceptance of } \\
\text { foreign practices tends to } \\
\text { be lower) }\end{array}$ \\
\hline \multirow{2}{*}{$\begin{array}{l}\text { Technological } \\
\text { capability }^{2}\end{array}$} & $\begin{array}{l}\text { Low } \\
\text { (limited absorptive } \\
\text { capacity for the } \\
\text { foreign know-how) }\end{array}$ & Crossvergence & Divergence \\
\hline & $\begin{array}{l}\text { High } \\
\text { (absorptive capacity } \\
\text { for the foreign } \\
\text { know-how is high) }\end{array}$ & Convergence & Transvergence \\
\hline
\end{tabular}

Cultural embeddedness refers to the common values and ties amongst firms and their constituencies (SuarezVilla, Rama, 1996, as cited in Gupta \& Wang, 2003, p. 70).

2 Technological capability refers to comprehensive knowledge about a broad spectrum of technological options, ranging from simple to high technologies, and the ability to evaluate and select technologies, to utilize, adapt, and improve them, and to further develop them (Hillebrand/Messner/Meyer-Stamer 1994, as cited in Gupta/Wang 2003: 70).

Source: Adapted according to Gupta and Wang (2003).

According to the above matrix, convergence to the dominant global model, i.e. Anglo model, is possible in situations when cultural embeddedness is low (the acceptance of foreign practices tends to be higher) and organizations have high technological capability (they have a better absorptive capacity for the foreign know-how and can adopt the global best practice model); (2) crossvergence or firm-specific hybrid between domestic and foreign elements is more likely when the firms have low technological capability (they can compete at best using global know-how that is widely available with high costs of adoption because of their limited absorptive capacity), and therefore must add some home-based advantages; (3) when cultural embeddedness is high, foreign elements are not readily accepted, so if the firms lack technological capability, they may still survive or flourish by leveraging their local relationships, which is likely to generate divergence in their business model oriented towards local culture; (4) if organisations have strong technological capability, then they are likely to adopt a transvergence approach to identify and exploit opportunities locally or globally, and thus to better respond to their cultural mandates (Gupta/Wang 2003: 71-72). The culture and technology may not be substitutes or opposing forces in the globalization process - both can work together in complementary ways (p. 75). 
In the case of HRM in Serbia the cultural embeddedness is often perceived as high, so overseas elements may not be readily accepted and successfully implemented in some HRM areas, such as performance appraisal and pay for performance as being incongruent with high collectivism and high egalitarism embedded in the Serbian national culture (Bond et al. 1982; Leung/Bond 1984; Hui et al. 1991; Easterby-Smith et al. 1995; Huo/Von Glinov 1995; Ramamoorthy/Carroll 1998; Zhou/Martocchio 2001; Aycan 2005). The transvergence perspective seems to be appropriate in explaining new developments in these HRM areas in Serbia, since many Serbian HRM managers attempt to identify and exploit performance appraisal systems locally and globally, and thus to better respond to their own cultural requests.

\section{Human resource management practices in Serbia}

Serbia was a constitutive part of the former Yugoslavia for more than 45 years. Before the Second World War Serbia belonged to the Kingdom of Yugoslavia, which was economically quite weak. At that time the Serbian economy had a huge agricultural sector with a share of almost 55\% in GNP (Grđić 1953: 55). During the Great War 1914-1918 Serbia lost the great portion of its emerging industrial sector, and the majority of its male population $(62 \%$ of the total number of men aged between 18 and 55 years). The private industrial sector was characterised by small, rather immature companies. Decisions regarding personnel issues were principally made by the general management.

After the Second World War, during more than 45 years, Serbia experienced a communist regime, which influenced the societal values, corporate governance and the structure of organizations. Economic development of Serbia was characterised by fast industrialisation and promotion of migration of labour from the agricultural sector to newly created industrial regions and cities. However, very high turnover, continuous shortfall of qualified employees and very high absenteeism were challenges for industrial state-owned companies to deal with on an almost daily basis. Quite a unique characteristic of the Serbian management system after the Second World War was introduction of selfmanagement system which assumed some delegation of power to the workers, although the Communist Party continued to be informally but actively involved in the management of companies.

At the beginning of 1990s, the former Yugoslavia started disintegrating with armed conflict taking place in several of the former Yugoslav republics. At the beginning of 2000 Serbia established a democratic political regime and started the renewed transition process (the first transition was attempted in the early 1990s) towards a market economy. Nowadays, Serbia has a population of 7.3 million, which is largely concentrated in the main cities. It is faced with a deep economic crisis reflected through high unemployment rate (24\%), low GNP 
growth rate, increased poverty, rising budgetary deficit and sensitive political requirements relating to the EU accession process.

\section{The traditional HRM mode}

The position and role of the HRM function in Serbian companies has been traditionally weak. The law on self-management in 1950s introduced Workers' Councils in all enterprises, which were supposed to participate in the management of companies together with the managers, who represented the interests of state. All important decisions about personnel issues (such as salaries, safety, paid leaves and training) were made by Workers' councils. Trade unions also had an important role regarding 'collective bargaining', employee benefits and services (e.g. cheaper nutrition on the job, health protection, establishing law departments within trade unions aimed to support employees in their disputes against management etc.). In 1957, three important laws for regulation of personnel issues were enacted: (1) Law on Labour Relations, which introduced higher autonomy to enterprises in making decisions regarding working conditions and labour relations, (2) Law on the Distribution of the Total Income, which also made firms more autonomous in creating pay schemes, and (3) Law on Pension Insurance. These laws brought more independence to enterprises. However, the discretion regarding personnel issues was still relatively limited by legislation. Enterprises could for example decide how many persons they would employ, but the law prescribed the employment procedure and wages criteria. In the following years personnel departments started to introduce some professional methods, such as: job design, job assessment, planning and staffing, training (apprenticeship, probation, mentoring, and provision of scholarships, part-time learning), promotion of work safety procedures, and social assistance to employees. However, the personnel function was rather immature as compared to other business functions and had quite weak organizational position. There were no qualified HR professionals, since the HR profession was not recognized as an important profession, so there was a lack of appropriate university programs.

During the 1970s, many Serbian enterprises started to fill-in personnel positions with individuals with university degrees in law or organizational sciences. The 1974 Constitution and the 1976 Labour Law promoted further development of the self-managed system in the former Yugoslavia. They guaranteed to all citizens the right to work and promoted the policy of full employment and relatively high level of job security. Despite major improvements when compared with other communist economies personnel function was highly administrative, and not really involved in decision making regarding personnel issues (Kavran 1976). The HRM (personnel) practices continued to be rather immature and focused primarily to the administrative role of the HRM function, often called the "Personnel Function". It typically included the following, 
mainly clerical, activities: keeping the personal files of the employees, taking care about legal issues concerning paid leaves, maternity leaves and other administrative issues required by the Serbian Labour Code and other relevant legislation, organization of socializing among the employees and informing the employees about important events in the company. Regarding the organizational location of the "Personnel Function" it was often grouped together with legal and support operations within the same department. Micro-organizational structure of the Personnel Unit consisted of two positions: Personnel Manager (often lawyer) and Personnel Clerk. Some administrative activities related to legal requirements were usually carried out by the Legal Clerk located within the Legal Department. Such organisational design produced quite detrimental outcomes such as: further mistreatment of this function within the organization, particularly by top management, and restraining further growth of the Personnel function with regard to its professional competence in long term. As the consequence of both ineffective professional advance of HR staff and misplaced position of the Personnel Unit along the organizational hierarchy all important HR decisions (such as recruiting new staff, firing, wages etc.) were made by managing director of the company. Although in many companies the executives would like to believe that "people are our most important asset" they could not understand how the HR function makes that vision a certainty (Becker et al. 2001). As such, the tradition of performing the "reactive" personnel function in Serbian companies actually represents the first phase in the evolution of this function (Cascio 1995) or the Service Model (Fitz-enz 2002) related to the period from the beginnings (the period of the World War I) until the 1960s. It is far away from the HRM concept, which assumes the following: (1) strategic orientation of HRM and its close link with business strategy, (2) increased role of line managers in HRM as the consequence of downsizing HR departments, (3) emphasized link between HRM and organizational performance, (4) more emphasis on individual forms of interaction and representation, and (5) a reorientation from a humanistic to a more organizationally driven value system (Mayrhofer/Larsen 2006).

\section{The post-socialist vigour}

It is widely recognized that Serbia is a transition straggler. This could be an important fact in analyzing transition impelled changes in managerial practices including the HRM. Actually, transition has formally started as early as in 1989 but the process was suppressed during the 1990s due to the ruling politics and corresponding policies in Serbia. Transition reforms in the country were deteriorating until $2001^{9}$ and even inherited features of the previous semi-market labour managed system were abandoned. Nevertheless, some privatization took

9 According to the EBRD (2009) data the sum of transition progress indicators for Serbia has moved from 14.67 in 1990 (index 133 of the average for all transition economies) to 13.33 in 2000 (index 54 of the average). 
place in accordance to the federal insider privatization scheme - around $35 \%$ of social capital in $30 \%$ of firms $(1,100)$ was subject to privatization but that figure was reduced under the 1994 "revaluation act" thus making a poor share of privatized capital in the country by the end of the nineties. After the democratic changes in autumn 2000, several hundred firms advanced in privatization by making use of the newly established market exchange rate. The previous privatization program (that was adopted in 1997) has defined free distribution of shares to the employees proportional to the years of employment valued in foreign currency (the scheme was not working until the end of 2000 due to severe undervaluation of the exchange rate which was well below its market value). The old nomenclature made use of new opportunities trying to quickly acquire shares, which was a signal for the Government to bring to an end this privatization program.

By the end of 2003 around 1,000 companies were privatized, but in the subsequent six years less than 1,000 extra companies finalized privatization procedures whereas a big share of capital remained state controlled primarily in the so-called public sector (and not necessarily public in standard terms). The reduced speed in privatization went together with a slowdown in other reforms after mid-2003. This slowdown had an impact on lower GDP growth and on general economic environment, although some adverse effects on growth were partially offset by the inflow of capital through FDI-s. Delay of reforms was particularly remarkable in institutions building that could be represented by some of the EBRD indicators on transition progress that are basically institutional like enterprise reform and restructuring, competition policies, infrastructure and financial markets reforms (Cerović/Nojković 2008). Furthermore, the market structure in many important industries did not develop in the desired direction and in some cases market structure has deteriorated (Cerović 2009). This unexpected result emerges with unbalanced pace of reforms when one-move reforms like privatisation and liberalization are followed by an uneven development of institutions, which in turn, depends on inherited conditions (and is even slower when goes below an achievable level as we have remarked in Serbia). This could produce another important implication when governance and management progress are considered.

An important issue is whether the transition process has influenced some changes in a traditional mode of HRM practices in Serbia. There were a few studies on changes in HRM practices in Serbia (Bogićević Milikić et al. 2008; Bogićević Milikić/Janićijević 2009; Bogićević Milikić et al. 2010a; Bogićević Milikić et al. 2010b), which shed some light on HRM developments during a post-socialism in Serbia. Overall, they indicated that despite the fact that some incremental changes were evident, it seemed that new conceptualization of the personnel/HR function was a quite slow and gradual process in Serbia. 
One study (Bogićević Milikić et al. 2008) of HRM practices in 38 randomly selected Serbian companies focused on the elements of the Serbian HRM model, the differences between the Serbian and the North American HRM models and prospective for the Serbian HRM model to converge with or diverge from the North American HRM model in the future. The study indicated that the formal HRM function in Serbia would be better considered as still promoting a concept of personnel management then a HRM concept, as it is primarily concerned with bureaucratic clerical activities, rather than being involved in strategy and policy HR decision making, which is consistent with the findings in some other transition economies (Tung/Havlovic 1996). The study suggested that some HRM practices in Serbia, as for instance the weak role of trade unions, do converge with the North American HRM model, in spite of highly incompatible Serbian cultural context and strong trade union tradition, which, in fact, implies that, in some HRM areas, institutional factors and transition process, in spite of a large cultural and traditional incongruence, may effectively facilitate the convergence of HRM practices. On the other hand, the study indicated that the role and scope of the HRM function and HR strategy, performance appraisal and performance related pay, staffing practices, employee development and employee communication largely diverge from those of the US. This is congruent with the thesis that the organizational autonomy on which the HRM concept is advocated in the US is neither espoused nor practiced elsewhere in Europe (Brewster 1993) and with the findings of some other studies on HRM in transition economies (Koubek/Brewster 1995; Tung/Havlovic 1996; Alas/Svetlik 2004; Koubek/Vatchkova 2004; Zupan/Kaše 2005).

The second accessible study (Bogićević Milikić/Janićijević 2009) attempted to investigate whether the speed of transition dominantly shaped the HRM developments in post-socialist countries, namely in Serbia and Slovenia, which used to be constitutional parts of the former Yugoslavia and used to share the same political and cultural background for many years. The analysis was focused on the following areas of HRM: the role of the HR function, HRM strategy involvement, training and development, performance measurements and rewards, employee relations and the role of trade unions. The research findings show that the HRM policies and practices in Serbia and Slovenia, regardless of the shared background and similar cultural values, diverge in all investigated aspects. The data for both countries suggest that the role of the HRM function is quite different in two countries: Slovenia is tremendously closer to EU countries than Serbia. In Slovenia, as well as in Europe, the HR department has a more profound role in strategy formulation and implementation. Regarding the primary responsibility for major HRM policy decisions, the study suggested that in the Serbian companies, contrary to the Slovenian and the European ones, the dominant role is given to the line management, i.e. to the General Manager, as it was the case during the communist era. The following explanations were offered for deeper understanding of identified differences between Serbia and Slovenia: 
(1) higher competence of HR professionals and better supply of HR professionals on the labour market in Slovenia than in Serbia, due to a longer and greater availability of HRM education and training courses; (2) large portion of included Serbian companies have only recently established HR departments, so HR managers have less than five years of experience in HRM whereas in the rest of selected companies traditional Personnel units still operate; (3) lack of awareness of human resources as a possible source of competitive advantage among Serbian top managers; (4) a high degree of centralisation and prevailing autocratic leadership style in Serbian companies assuming that majority of strategic decisions are made by a very small team of top managers, without consulting all functional or middle managers. The authors concluded that the transition process, per se, may explain almost all renowned differences between HRM practices in Serbia and Slovenia, as it succeed to overcome the cultural barriers imposed by the dimensions of Slovenian and Serbian national culture in the case of performance appraisal, flexible patterns of work, recruitment of managers and merit/performance - related pay. However, the study has also indicated that there were some similarities of HRM practices in Slovenia and Serbia regarding low involvement of different staff categories, other than managers, in strategic and financial matters, as well as equality in the use of performance appraisal for different staff categories. The authors explained the recognized similarities through the common cultural context in two countries: high power distance, which prevented higher participation of all parties within strategic management, and strong collectivism and femininity which promote equality among different staff categories. The authors proposed that the Serbian HRM model will converge to the Slovenian HRM model, whereas the scope and speed of convergence will depend on the speed and success of the transition process in Serbia.

The third study (Bogićević Milikić et al. 2010a) addressed whether globalization implies convergence and therefore utilization of unified HR practices across companies or whether a specific cultural and institutional context may prevent convergence. The authors investigated the differences between the Serbian companies and the foreign companies operating in Serbia, assuming that foreign companies operating in Serbia utilize unified HR practices which represent a certain type of "global HRM model" as comprising possible influences of different institutional and cultural contexts of all countries from where selected foreign companies operating in Serbia originate. The research findings (from the sample of 144 randomly selected companies) presented in this study have in fact confirmed that there is a general tendency toward convergence of HRM practices, but with a clear indication of areas of HRM where the convergence process is still absent, is very slow or it is mixed with some divergent forces. As a major driving force for convergence of HRM practices the authors pointed out the globalization which implies more frequent and more intensive competition and cooperation of domestic companies with foreign ones. As a major driving 
force for divergence of HRM practices the authors saw in the authoritarian national culture and the institutional factors such as the lack of competence and knowledge of HRM in Serbian companies.

The most recent study (Bogićević Milikić et al. 2010b) aimed to shed light on the HRM model in Serbia after ten years of the renewed transition process, by surveying a considerably large sample comprising 144 companies operating in Serbia. The study suggests that the HRM concept, as such, still does not exist in the observed Serbian companies: (1) strategic orientation of HRM is still not fully present among selected companies; (2) lack of professional competence of the head of personnel/HR department is evident, since they are mostly recruited from the non-personnel positions either from or outside the organization; (3) rare use of external providers for various HR services; (4) increased role of line managers in HRM as the consequence of downsizing HR departments has not been found, since over-employment of HR departments is present in almost all observed companies; (5) emphasized link between HRM and organizational performance has not been found, (6) more emphasis on individual forms of interaction and representation in Serbian companies has not been found either the role of trade unions is very weak and communication with all employee categories is inadequate and insufficient either through the individual or collective forms of interaction and representation, (7) there is no evidence of a reorientation from a primarily humanistic to a more organizationally driven value system. However, the study revealed some signs of positive change, such as: the organization of the HRM function within the separate department, appearance of the position of the HR manager, university background of HR managers in subject areas other than Law (although lawyers still dominate the profession), higher inclusion of HR departments in making major policy decisions regarding HR issues, existence of written policy in some HR areas, such as pay and benefits, recruitment and selection and training and development, more HR staff with the university degree instead of clerical staff, etc. Although some new developments regarding the HRM function have been found, any more comprehensive application of the HRM concept, according to the authors, would require further changes within institutional and organizational environments, such as: (a) speeding up the transition process with particular attention to the competition policy, institutions and attraction of FDI, (b) changing the cultural values towards lowering Power Distance and high Uncertainty Avoidance to create necessary conditions for changes to take place, and (c) further advancing of professional competence of HR departments (through additional training and development of the HR staff, ease of foreign companies` entry to allow for transferring contemporary HR trends and practices from Western developed economies into the Serbian organizations, creation of professional associations and networking in the HR area, development of the market for HR services, etc.). 


\section{Lessons learned and open issues in human resource management in transition countries}

Twenty years of post-socialism in Serbia provided a ground for certain conclusions to be drawn and some lessons to be learned when it comes to changes in the field of HRM.

First, HRM is certainly a part of the transitional process in Serbia and a field in which significant changes have been happening during the last twenty years. All available studies on Serbian HRM practices indicate that changes of HRM in Serbia are fairly evident, regardless of the disagreements about the direction and the degree of these changes. However, it is also noticeable that the changes have not been sufficient enough to fully change the Serbian traditional Personnel Management model and move it closer to the modern HRM concept.

Secondly, it seems that two groups of factors influence the changes in the field of HRM, and we can observe them as two types of forces within the Force Field Theory (Lewin 1951): the forces pushing HRM in Serbia towards changes and the forces pushing HRM in Serbia away from expected changes. The first group of forces includes two main facilitators of HRM's changes: (1) the transition process as a comprehensive change of social, political and economic system, which includes privatisation and free entry of foreign investors; and (2) the globalisation process, which includes strengthening of the institutional pressure from the global context towards implementation of generally accepted models in all areas of companies' business operations, and hence in the area of HRM as well. The second group of forces pushing HRM in Serbia in keeping the status $q u o$, are the following: (1) the institutional context which includes both legislation and quality of the relevant institutions, as well as the state of affairs on the labour market and in the sector of education; and (2) the national culture, which determines the behaviour of both employees and managers in Serbia.

Finally, HRM changes in Serbia seem not to be very homogenous: they differ from one field of HRM to another, in terms of both the degree and the direction of noticed changes. In some HRM areas, the changes advanced in the direction of acceptance of the Anglo-Saxon HRM model. Such areas are, for example, launching of separate HR departments and their staffing, HRM strategies and policies, etc. On the other hand, in some other HRM areas, such as performance appraisal and employee communications, expected changes either did not happened at all, or they were moving in the opposite direction compared to the HRM concept present in developed Western countries. Therefore, we may conclude that HRM changes in Serbia do not have a clear appearance of neither convergence nor divergence. The changes in the HRM field in Serbia have rather the character of crossvergence or transvergence.

However, even though we have learned some lessons, there are still some open issues in the field of HRM during post-socialism, which certainly present a 
fruitful field for future research. The most important open issue regarding the HRM changes in Serbia is the relative strength of the forces pushing towards and away from the HRM changes in the future. Will the processes of transition and globalisation overwhelm the strength of institutional context and national culture, and thereby accelerate the convergent changes of Personnel management model towards the HRM concept, or will the institutional context and the Serbian national culture block all further changes of HRM and produce some mixture of traditional personnel management model and a HRM concept? One important issue here is certainly related to the speed of accession of Serbia to the EU and its relevance to the relationship between the forces promoting and impeding further HRM changes in Serbia.

The second open issue is the character of HRM changes in Serbia now and in the future. Available studies clearly show that post-socialism in most cases does not produce a pure convergence or divergence of HRM practices, at least not in the short term. Whether companies in Serbia will transform themselves according to the model of transvergence or crossvergence depends on their cultural embeddedness and absorptive capacity. However, one important issue here is whether the post-socialism would promote some new distinctive HRM model in post-socialist countries, or the specific HRM models in different postsocialist countries would eternally move through different stages of crossvergence and transvergence without the final end in convergence or divergence from the Western HRM concept.

The third open issue is whether Serbian companies will have enough capacity for organizational learning to adopt new practices in the area of HRM? Furthermore, it would be interesting to investigate which factors influence the process of organizational learning through which a new model of HRM in Serbian companies could be accomplished; finally, what could be done to improve absorptive capacity of Serbian companies in order to speed up the process of learning of new HRM practices?

Finally, the fourth open issue is whether it is and how it is possible to influence the national culture as one of the most important factors of changes in the field of HRM. Building an institutional context suitable for development of a HRM concept is a difficult, but a fairly feasible task with predictable barriers. But, it is less clear whether it is possible at all, in what time frame and by which means, to influence the changes of the national culture' values in post-socialist countries, which may prevent necessary changes in the traditional Personnel management model.

\section{References}

Alas, R./Svetlik, I. (2004): Estonia and Slovenia: Building Modern HRM Using a Dualist Approach, in: Brewster, C. Mayrhofer, W. \& Morley, M. (Eds.): Human Resource Management in Europe: Evidence of Convergence? Elsevier Butterworth-Heinemann, 353-383. 
Aycan, Z. (2005): The interplay between cultural and institutional/structural contingencies in human resource management practices, in: International Journal of Human Resource Management, 16, 7, 1083-1119.

Becker, B.E./Huselid, M.A./Ulrich, D. (2001): The HR Scorecard: Linking People, Strategy and Performance. Boston: Harvard Business School Press.

Bjorkman, I. (2006): International human resource management research and institutional theory, in: Stahl, G.K./Bjorkman, I. (Eds.): Handbook of Research in International Human Resource Management, Cheltenham, UK: Edward Elgar, 463-474.

Bogićević Milikić, B./Janićijević, N. (2009): HRM trends in transition economies: two reflections of the shared background, in Sociology, LI, 2, 157-176.

Bogićević Milikić, B./Janićijević, N./Nojković, A. (2010a): Globalization and convergence of human resource management practices in transition economies: the case of Serbia, 26th EGOS Colloquium, Lisbon: Waves of Globalization: Repetition and difference in organizing over time and space, June 28-July 3, Lisbon, Portugal.

Bogićević Milikić, B./Janićijević, N./Cerović, B./Nojković A. (2010b): Building a Human Resource Management Model in Eastern European Transition Economies: Evidence from Serbia, Advances in Business-Related Scientific Research Conference (ABSRC 2010), 8-10 September, Sardinia, Italy.

Bogićević Milikić, B./Janićijević, N./Petković, M. (2008): HRM in Transition Economies: The Case of Serbia, in South East European Journal of Economics and Business, 3, 2, $75-88$.

Bond, M.H./Leung, K./Wan, K.C. (1982): How does cultural collectivism operate? The impact of task and maintenance contributions on reward distribution, in: Journal of Cross-Cultural Psychology, 13, 186-200.

Brewster, C. (1993): Developing a 'European' model of human resource management, in: International Journal of Human Resource Management, 44, 765-784.

Brewster, C./Mayrhofer, W./Morley, M. (2004): Human Resource Management in Europe: Evidence of Convergence? Elsevier Butterworth-Heinemann.

Brewster, C. (2006): Comparing HRM policies and practices across geographical borders, in: Stahl, G.K. and Bjorkman, I. (Eds.): Handbook of Research in International Human Resource Management, Cheltenham, UK: Edward Elgar, 68-90.

Cascio, W.F. (1995): Managing Human Resources: Productivity, Quality of Work Life, Profits. $4^{\text {th }}$ ed., McGraw-Hill.

Celestino, M. (1999): Graduate education programs with international vision: how graduate business schools are transcending borders, in: World Trade, 12, 7, 86-92.

Cerović, B. (2009): Transition, Transition Progress and Global Crisis: Serbia and Other Countries, in Praščević et al. (Eds.): Economic Policy and Global Recession, Vol 1. Belgrade: Faculty of Economics, 321-332.

Cerović, B./Nojković, A. (2008): Usporavanje reformi u Srbiji: trošak neiskorišćenih mogućnosti, in: Zec, M. and B. Cerović (Eds.): Kuda ide Srbija - ostvarenja i dometi reformi, Beograd: Ekonomski Fakultet, 23-42.

Cole, R. E. (1973): Functional alternatives and economic development: An empirical example of permanent employment in Japan, in: American Sociological Review, 38, 424-38. 
DiMaggio, P./Powell, W.W. (1983): The Iron Cage Revisited: Institutional Isomorphism and Collective Rationality in Organizational Fields, in: American Sociological Review, 48, 4, 147-60.

Easterby-Smith, M./Malina, D./Yuan, L. (1995): How Culture Sensitive is HRM? A Comparative Analysis of Chinese and UK Companies, in: International Journal of Human Resource Management, 6, 1, 31-59.

Evans, R. (1970): Evolution of the Japanese system of employer-employee relations, 18681945, in Business History Review, 44, 1, 110-25.

Fitz-enz, J./Davison, B. (2002): How to Measure Human Resources Management. $3^{\text {rd }}$ ed., McGraw Hill.

Gooderham, P./Morley, M./Brewster, C./Mayrhofer, W. (2004): Human Resource Management: A Universal Concept? In C. Brewster, W. Mayrhofer \& M. Morley (Eds.): Human Resource Management in Europe: Evidence of Convergence? Elsevier Butterworth-Heinemann, 1-26.

Grđić, N. (1949): Razvoj privrede Srbije i Vojvodine od oslobođenja od Turaka, in: Proizvodne snage NR Srbije, Ekonomski institut NR Srbije, Belgrade.

Gupta, A.K./Wang, H. (2003): Globalization And Convergence-Divergence Debate: Strategic Perspectives For Emerging Markets, in: Journal Of Business And Economics Research, 1, 2, 69-76.

Hofstede, G. (1980): Motivation, Leadership and Organization: do American Theories Apply Abroad, in: Organizational Dynamics, summer, 42-46.

Hofstede, G. (2001a): Culture's Consequences. Thousand Ouks, CA: Sage Publications.

Hofstede, G. (2001b): Difference and Danger: Cultural Profiles of Nations and Limits to Tolerance, in M. Albrecht (Ed.): International HRM: Managing Diversity in the Workplace, London: Blackwell, 9-23.

Holden, L. (2001): International human resource management, in: Beardwell, I. and Holden, L. (Eds.): Human Resource Management: a contemporary approach, third edition, Prentice Hall, 633-678.

Hui, C.H./Triandis, H.C./Yee, C. (1991): Cultural differences in reward allocation: Is collectivism the explanation? in: British Journal of Social Psychology, 30, 145-157.

Huo, Y.P./Von Glinov, M.A. (1995): On Transplanting Human Resource Practices to China: A Culture-Driven Approach, in: International Journal of Manpower, 16, 9, 3-11.

Kavran, D. (1976): Kadrovska funkcija u udruženom radu, Belgrade: Suvremena administracija.

Kerr, C./Dunlop, J.T./Harbison, F./Myers, C.A. (1960): Industrialism and Industrial Man. Cambridge, Mass.: Harvard University Press.

Kordonsky, S. (1992): Pressure groups in the social structure of reforming society, in: Communist Economies and Economic Transformation, 4, 1, 85-95.

Koubek, J./Brewster, C. (1995): Human resource management in turbulent times: HRM in the Czech Republic, in: The International Journal of Human Resource Management 6, 2, 223-247. 
Koubek, J./Vatchkova, E. (2004): Bulgaria and Czech Republic: Countries in Transition, in Brewster, C., Mayrhofer, W. and Morley, M. (Eds.): Human Resource Management in Europe: Evidence of Convergence? Elsevier Butterworth-Heinemann Laurent, 313351.

Leung, K./Bond, M.H. (1984): The impact of cultural collectivism on reward allocation, in: Journal of Personality and Social Psychology, 47, 793-804.

Lewin, K. (1951): Field Theory in Social Science. New York: Harper \& Row.

Li, J./Karakowsky, L. (2001): Do we see eye to eye? Implications of cultural differences for cross-cultural management research and practice, in The Journal of Psychology, 135, 501-517.

Mayrhofer, W./Larsen, H.H. (2006): European HRM: a distinct field of research and practice, in Larsen H.H. and Mayrhofer W. (Eds.): Managing Human Resources in Europe, Routledge, 1-17.

McKinley, W./Sanchez/Schick, A.G. (1995): Organizational downsizing: Constraining, cloning, learning, in Academy of Management Executive, 9, 3, 32-44.

Ralston, D./Holt, D./Terpistra, R./Kai-Cheng, Y. (1997): The Impact of National Culture and Economic Ideology on Managerial Work Values: A Study of the United States, Russia, Japan and China, in: Journal of International Business Studies, 28, 1, 177-207.

Ramamoorthy, N./Carroll, S.J. (1998): Individualism/Collectivism Orientations and Reactions Toward Alternative Human Resource Management Practices, in: Human Relations, $51,5,571-588$.

Rollinson, D./Broadfield, A. (2002): Organisational Behaviour and Analysis. Second edition. Prentice Hall.

Schneider, S.C. (1992): National vs. Corporate Culture: Implications for Human Resources Management, in: Pucik, V./Tichy, N./Barnett C. (Eds.): Globalizing management, New York: John Wiley \& Sons, 452-479.

Schneider, S./Barsoux, J. (1997): Managing Across Cultures. Hertfordshire: Prentice Hall Europe.

Schuler, R.S./Rogovsky, N. (1998): Understanding compensation practice variations across firms: The impact of national culture, in: Journal of International Business Studies, 29, $1,159-77$.

Schuler R./Jackson S./Jackofsky E./Slocum, J. (2001): Managing Human resource in Mexico: A Cultural Understanding, in Albrecht, M. (ed): International HRM: Managing Diversity in the Workplace, London: Blackwell, 245-270.

Schwartz, S. H. (1994): Beyond individualism/collectivism: New cultural dimensions of values, in: Kim, U./Triandis, H. C./Kagitçibasi, C./Choi, S.C./Yoon, G. (Eds.): Individualism and collectivism: Theory, method and applications, Thousand Oaks, CA: Sage, 85-119.

Shaw, J.B./Fisher, C.D./Randolph, W.A. (1991): From materialism to accountability: The changing cultures of Ma Bell and Mother Russia, in: Academy of Management Executive, 5, 1, 7-20. 
Sorge, A. (2004): Cross-national differences in human resources and organization, in Harzing A.W./Van Ruysseveldt, J. (Eds.): International human resource management. London: Sage.

Sparrow, P./Hiltrop, J.M. (1994): European Human Resource Management in Transition. Hemel, Hempstead: Prentice Hall.

Sparrow, P./Hiltrop, J.M. (1997): Redefining the Field of European Human Resource Management: A Battle between National Mindsets and Forces of Business Transition, in Human Resource Management, 36, 2, 201-219.

Stone, D.L./Stone-Romero, E.F., (Eds.) (2008): The Influence of Culture on Human Resource Management Processes and Practices. Psychology Press \& Lawrence Erlbaum Associates.

Tayeb, M. (1995): The competitive advantage of nations: the role of HRM and its sociocultural context, in: International Journal of Human Resource Management, 6, 3, 588605.

Tayeb, M. (2005): International Human Resource Management: A Multinational Company Perspective. Oxford: Oxford University Press.

Trompenaars, F./Hampden-Turner, C. (2004): Managing People Across Cultures. Capstone Publishing.

Tung, R. L./Havlovic, S. J. (1996): Human resource management in transitional economies: the case of Poland and the Czech Republic, in: International Journal of Human Resource Management, 7, 1, 1-19.

Yip, G.S. (1992): Total global strategy: Managing for worldwide competitive advantage. Englewood Cliffs, NJ: Prentice-Hall.

Zhou, J./Martocchio, J.J. (2001): Chinese and American Managers' compensation award decisions: A comparative policy-capturing study, in: Personnel Psychology, 54, 15145 .

Zupan, N./Kaše, R. (2005): Strategic human resource management in European transition economies: building a conceptual model on the case of Slovenia, in: International Journal of Human Resource Management, 16, 6, 882-906. 